\title{
Alcanivorax strain detected among the cultured bacterial community from sediments affected by the 'Prestige' oil spill
}

\author{
Jorge Alonso-Gutiérrez ${ }^{1}$, Maria M. Costa ${ }^{1}$, Antonio Figueras ${ }^{1}$, Joan Albaigés ${ }^{2}$, \\ Marc Viñas ${ }^{3,4}$, Anna M. Solanas ${ }^{3}$, Beatriz Novoa ${ }^{1, *}$ \\ ${ }^{1}$ Instituto de Investigaciones Marinas, CSIC, Eduardo Cabello 6, Vigo 36208, Spain \\ ${ }^{2}$ IIQAB-CSIC, Jordi Girona 18-26, 08034 Barcelona, Spain \\ ${ }^{3}$ Department of Microbiology, University of Barcelona, Diagonal 645, 08028 Barcelona, Spain \\ ${ }^{4}$ GIRO Technological Centre, Rambla Pompeu Fabra, 1, 08100 Mollet del Vallès, Spain
}

\begin{abstract}
Sediments sampled next to the Cíes Islands, a natural reserve of the National Park of Atlantic Islands in Ría de Vigo (Spain), 3 mo after the first tide of fuel from the 'Prestige' tanker arrived, were chemically and microbiologically characterized. The chemical analysis of the sediments, using oil fingerprinting techniques, showed the occurrence of fresh 'Prestige' fuel oil with a background of older hydrocarbon contamination. The cultured bacterial community of the contaminated sediments harbored a high population of total heterotrophs and alkane degraders and a small proportion of aromatic-degrading bacteria. Based on partial 16S ribosomal RNA gene sequence data, 37 different bacterial strains, isolated in diluted marine agar, were detected. Most of them were classified as members of the groups Gammaproteobacteria (59\%) and Alphaproteobacteria (21\%), although members of the Bacteroidetes (10\%) and of Firmicutes $(10 \%)$ were also found. Some of the different identified bacteria have previously been described as fuel oil-degrading species such as Alcanivorax, Shewanella, Vibrio, Pseudoalteromonas and Marinomonas. Seven independent isolates were able to grow with hexadecane. However, these 7 strains are grouped under the same phylotype, based on the 16S rRNA gene sequence, and were closely related to Alcanivorax borkumensis (Gammaproteobacteria). No aromatic-degrading activities were detected among the culturable bacteria. The presence of fresh fuel without a detected level of biodegradation suggests that Alcanivorax was an early colonizer after the 'Prestige' oil spill. To our knowledge, the isolation of Alcanivorax from environmental samples without the aid of an enrichment procedure has not been previously reported. Our results suggest the ability of Alcanivorax to compete and coexist with other heterotrophic marine bacteria in an oil polluted marine environment rich in the nutrients $\mathrm{N}$ and $\mathrm{P}$.
\end{abstract}

KEY WORDS: 'Prestige' oil spill · Alcanivorax $\cdot$ Pollution $\cdot$ Hydrocarbon contamination

\section{INTRODUCTION}

In November 2002, the oil tanker 'Prestige' broke up and sank 120 nautical miles off the Galician coast (NW Spain) during a storm, leading to one of the largest known oil spills in the region. More than $80 \%$ of the $77000 \mathrm{t}$ cargo is thought to have been spilled. The product was heavy fuel oil No. 6 with a density of $0.995 \mathrm{~g} \mathrm{~cm}^{-3}$ and a composition of $2.28 \% \mathrm{~S}, 22 \%$ aliphatics, $50 \%$ aromatics and $28 \%$ of resins and asphalthenes (Alzaga et al. 2004). Large spills of heavy fuel oil are less usual than spills of crude oils and exhibit a different fate as they are barely dispersed in the water column and mainly stranded on the shoreline or sedimented in the form of patches or tar aggregates.

The 'Prestige' oil spread onto several $1000 \mathrm{~km}$ of the Spanish and French coasts, arriving at Vigo in the first week of December 2002. Many beaches and natural 
reserves, such as the National Park of the Atlantic Islands, have been affected since then.

The ecological importance of the islands prompted the present work, which was carried out in order to obtain information about the natural microbiota present in surface sediments and to study their potential for natural attenuation processes on heavy fuel oil biodegradation after the 'Prestige' oil spill. Chemical and microbiological analyses provide valuable data for assessing the intrinsic bioremediation capabilities of the sediments.

Bioremediation, defined as the act of adding nutrients or bacteria to contaminated environments to cause an acceleration of the natural biodegradation processes, is recognized as an appropriate oil spill response tool (Swannell et al. 1996). Adding nitrogen $(\mathrm{N})$ and phosphorous $(\mathrm{P})$ to the environment (biostimulation) has been a common bioremediation strategy to favor the growth of degrading bacteria. The use of allochthonous petroleum-degrading bacteria (bioaugmentation) obtained from enriched laboratory cultures has not yet been shown to be more effective than the stimulation of the autochthonous species of degraders (Swannell et al. 1996, Diez et al. 2005, Vinas et al. 2005a). Recently, an enhancement of biodegradation, especially of heavier alkanes and, even more so, of alkylated polycyclic aromatic hydrocarbons (PAHs), has been described in the treatment of the 'Prestige' oil using an oleophilic fertilizer in vitro and in field conditions (Jiménez et al. 2006, 2007).

Before the application of in situ bioremediation, it is advisable to search for indigenous hydrocarbondegrading microorganisms. There is limited information about the vast majority of oil-degrading marine bacteria, which remain uncultured, and even less is known about microbial species present in marine sediments contaminated with heavy fuels.

To our knowledge, only the experiments conducted after the 'Nakhodka' oil spill retrieved information about microbial populations adapted to heavy fuel oil. In this case, the development of microbial communities in polluted samples from natural beaches and water was studied, and the microorganisms later subjected to enrichment in batch culture. Under these conditions, adapted microorganisms were more easily grown in isolation media (Kasai et al. 2002). Different mole25 cular approaches, mainly involving 16S rRNA analysis such as PCR/DGGE (Kasai et al. 2001), clone libraries and specific oligonucleotide probes (Maruyama et al. 2003), were used in order to follow the changes in the degrading community. All these studies reached similar conclusions, which could be summarized as follows: (1) the total population of bacteria was almost stable and the accident had no long-term effects on its composition; $_{i}$ (2) the degraders of oil components showed a maximum population level immediately after the oil spill; (3) the oil-degrading community was predominantly composed of bacteria that closely resembled the aliphatic hydrocarbon decomposer Alcanivorax borkumensis, followed by the aromatic-degrading bacteria Cycloclasticus pugetii and Sphingomonas.

Several genera of marine bacteria capable of degrading petroleum hydrocarbons have recently been described such as Alcanivorax, Oleiphilus, Oleispira, Cycloclasticus and Marinobacter. These genera and a few others that are obligate consumers of oil hydrocarbons have been named obligate hydrocarbonoclastic bacteria (OHCB), which bloom after a pollution event. However, the types of hydrocarbon-degrading bacteria that may bloom depend on the latitude/temperature, salinity, redox conditions, and other physicochemical factors (Harayama et al. 2004, Yakimov et al. 2007). Indeed, it has recently been shown that biological factors, such as bioturbation, may also favor the development of oil-degrading communities in polluted environments (Cuny et al. 2007).

Alcanivorax borkumensis was isolated for the first time in the North Sea using $n$-tetradecane as the sole carbon and energy source (Abraham et al. 1998, Yakimov et al. 1998). In a relatively short period of time, the genus Alcanivorax has been isolated or detected by molecular techniques from samples taken from different places such as the Atlantic Ocean, the Mediterranean Sea, the North Sea, the Sea of Japan, the South China Sea and the Antarctic (Golyshin et al. 2003).

It is an aerobic organism that has been defined as a 'professional hydrocarbonoclastic bacteria', since it is an obligate consumer of alkanes and branched alkanes unable to grow on sugars or amino acids (Harayama et al. 2004, Head et al. 2006, Yakimov et al. 2007). Alcanivorax usually exists in low numbers in unpolluted waters and rapidly increases along coastlines and in oil-polluted waters (Harayama et al. 1999, Kasai et al. 2001, Syutsubo et al. 2001). Its capacity to grow on branched alkanes seems to be the reason why this genus becomes the major component of the bacterial population in oil-contaminated seawater in the presence of an adequate supply of $\mathrm{N}$ and $\mathrm{P}$ (Hara et al. 2003).

Like most hydrocarbon-degrading species, Alcanivorax spp. have been isolated using media enriched in fuel or any oil fraction (Liu \& Shao 2005), or in a very oligotrophic medium (Fernandez-Martinez et al. 2003), in order to avoid competition with heterotrophic marine bacteria, which usually outcompete hydrocarbondegrading species. Alcanivorax has also been isolated from heavy oil-polluted samples from the 'Nakhodka' oil spill in Japan. Again, Alcanivorax could only be isolated from oil-polluted sand, gravel and seawater after growing the polluted samples in nutrient-enriched cul- 
tures (Kasai et al. 2001, 2002, Roling et al. 2002). These experiments were performed in vitro or under artificial enrichment conditions, so their results cannot be directly extrapolated to the real environment. However, to answer the question of which microorganisms have particular significance for the removal of hydrocarbons from the environment, it could be useful to obtain evidence from culture-based studies that define the catabolic capabilities of candidate organisms and indicate the qualitative and quantitative importance of particular organisms in situ (Head et al. 2006).

In the present work, we report on a chemical and culture-based microbiological study of marine sediments affected by the 'Prestige' heavy fuel oil spill, 3 mo after the accident. Chemical fingerprinting was used to detect polluted sediments, verifying that no cross contamination from different sources other than the 'Prestige' fuel occurred. The most recently polluted sediments were used directly for a microbiological examination using non-selective media for the isolation of degrading bacteria. As far as we know, no previous study has tried to isolate degrading strains directly from heavy oil-polluted environmental samples without any prior enrichment procedure.

\section{MATERIALS AND METHODS}

Sampling. Surface sandy-gravel sediments next to Cíes Islands $\left(42^{\circ} 13.50^{\prime} \mathrm{N}, 08^{\circ} 53.57^{\prime} \mathrm{W}\right.$, National Park of Atlantic Islands, Vigo, Spain) (Station 1; Fig. 1) were collected by CIS (Centro de Investigaciones Submari- nas, Vigo) SCUBA divers in the subtidal zone (4 m water depth), 3 mo after the first 'Prestige' black tide reached the islands. Samples were collected from the upper $10 \mathrm{~cm}$ of sediment by means of sterilized flasks.

Once collected, samples were stored at $4^{\circ} \mathrm{C}$ and sent to the laboratory, where those for chemical analyses were frozen $\left(-20^{\circ} \mathrm{C}\right)$. Microbiological analysis of Station 1 was conducted immediately after sampling. Other samples for chemical analysis were collected at the same time from around the islands at the stations shown in Fig. 1, using a box-core dredge $(10 \times 16 \mathrm{~cm})$ and recovering the surface layer ( 1 to $2 \mathrm{~cm}$, approximately $300 \mathrm{~g}$ ).

Chemical analysis. The sediment samples (about $5 \mathrm{~g}$ ) were spiked with the surrogates (anthracene- $d_{10}$, pyrene- $d_{10}$ and benzo[a]pyrene- $d_{12}$ ) and extracted with a pressurized solvent extraction apparatus (Applied Separations) with hexane-acetone $(1: 1)$ at $110^{\circ} \mathrm{C}$ for $10 \mathrm{~min}$ in 3 cycles. The recovered extracts were treated overnight with recently activated copper for elemental sulfur removal, then carefully evaporated to near dryness, and dissolved with $0.5 \mathrm{ml}$ of $n$-hexane for further fractionation into aliphatic and aromatic hydrocarbons.

Fractionation was performed by column chromatography with $1 \mathrm{~g}$ anhydrous sodium sulfate (top), $6 \mathrm{~g}$ neutral alumina (middle) (activated at $350^{\circ} \mathrm{C}, 5 \%$ water deactivated) and $6 \mathrm{~g}$ silica gel (bottom) (activated at $120^{\circ} \mathrm{C}$ and $5 \%$ water deactivated). Two fractions were collected: (1) aliphatic hydrocarbons, eluted with $20 \mathrm{ml}$ of $n$-hexane and (2) polycyclic aromatic hydrocarbons with $40 \mathrm{ml}$ of $n$-hexane:dichloromethane (80:20). The
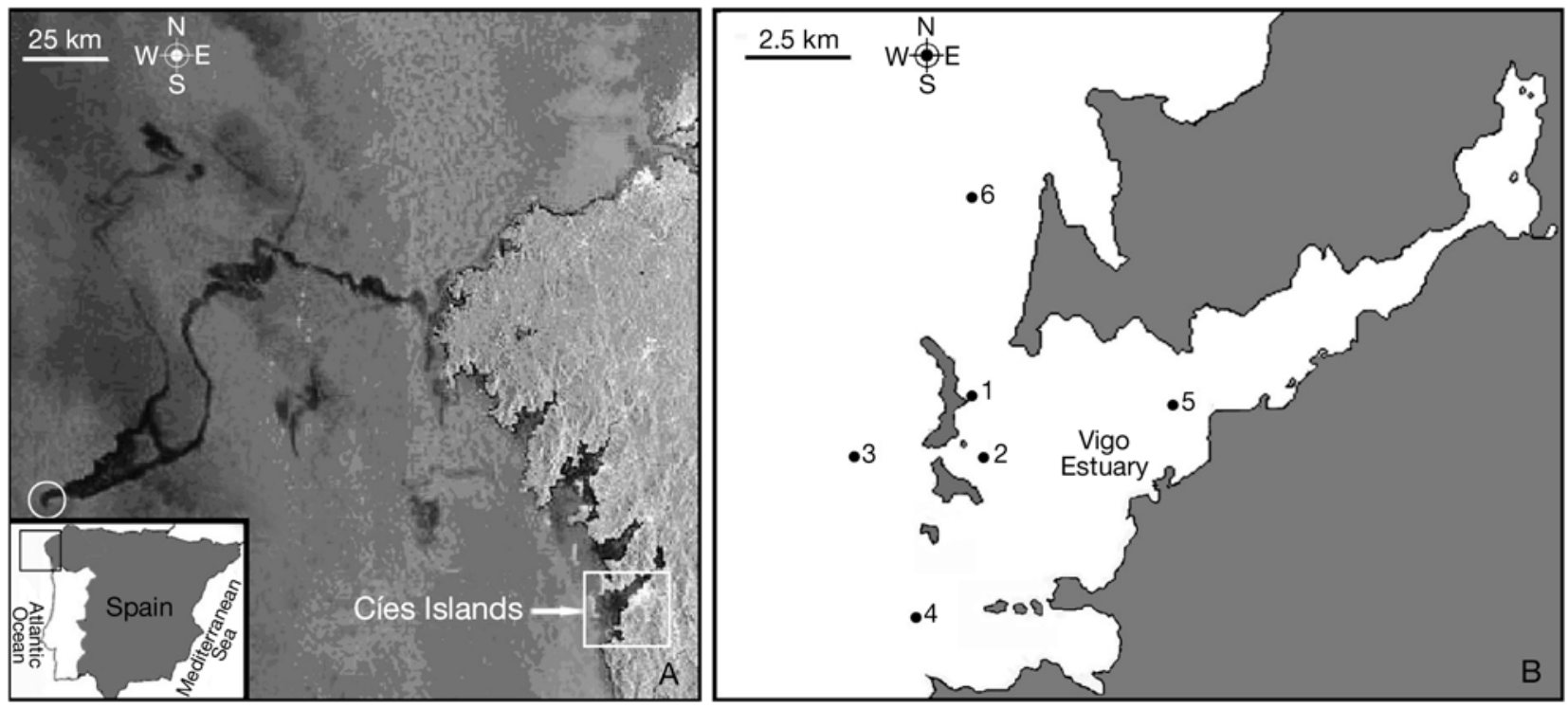

Fig. 1. (A) Satellite image (ENVISAT, http://envisat.esa.int/asar_oil_spill/) of the Galician coast after the spill of fuel from the 'Prestige' tanker on 17 November 2002. The white circle shows the position of the tanker just before sinking. (B) Detailed map of Vigo Estuary with the sampling stations (1 to 6) around the Cíes Islands 
collected extracts were concentrated and analyzed by gas chromatography coupled to mass spectrometry (GC-MS) using a Thermo-Electron Corporation system in the electron impact (EI) mode at $70 \mathrm{ev}$. The gas chromatograph was equipped with a split/splitless injector (splitless time: $0.80 \mathrm{~min}$, split flow $50 \mathrm{ml} \mathrm{min}^{-1}$ ) and a HP-5 MS capillary column of $30 \mathrm{~m} \times 0.25 \mathrm{~mm}$ i.d. $\times$ $0.25 \mathrm{~mm}$ film (J\&W Scientific). The initial column temperature was held for $1 \mathrm{~min}$ at $70^{\circ} \mathrm{C}$, then programmed to increase at a rate of $15^{\circ} \mathrm{C} \mathrm{min}{ }^{-1}$ to $150^{\circ} \mathrm{C}$ and then at $6^{\circ} \mathrm{C} \mathrm{min}{ }^{-1}$ to a final temperature of $320^{\circ} \mathrm{C}$, which was held for $10 \mathrm{~min}$. The carrier gas was helium at a constant flow of $1.2 \mathrm{ml} \mathrm{min}^{-1}$. The injector temperature was $310^{\circ} \mathrm{C}$, and the transfer line and ion source were held at 250 and $200^{\circ} \mathrm{C}$, respectively. Data were acquired in the full scan mode from 50 to $490 \mathrm{amu}$ (2.4 scans s$~^{-1}$ ) with 5 min of solvent delay and processed by the X-calibur software.

The peak areas of the target analytes were measured in the reconstructed ion chromatograms at $\mathrm{m} / \mathrm{z} 85$ for aliphatics, m/z 217 and 218 for steranes, m/z 191 for hopanes and the molecular ion for the aromatic hydrocarbons. Recoveries ranged from 70 to $110 \%$, except for naphthalene, where it was 40 to $60 \%$ due to its higher volatility. The relative standard deviation (RSD) of the molecular biomarker indices was $<5 \%$.

Bacterial isolation. Results from chemical analysis showed Station 1 as the most polluted. Sediments from this place were used to isolate bacteria. It seems that the sea currents or new input of pollutants, which still occurred at the time of sampling, made this part of the estuary hold a greater amount of pollution compared with neighboring areas.

Ten-fold dilutions of the sediments from Station 1 were spread directly onto agar plates containing $1 / 5$ strength of marine broth (Cultimed) and $1.5 \%(\mathrm{w} / \mathrm{v})$ agar. Colony-forming units (CFUs) were determined after incubation at $20^{\circ} \mathrm{C}$ for $7 \mathrm{~d}$, in order to assess the most abundant culturable bacteria. For morphological and biochemical characterization, pure cultures were obtained from the most abundant culturable bacteria by streaking them on marine agar and storing them in marine broth with $15 \%$ glycerol at $-80^{\circ} \mathrm{C}$ for subsequent analysis.

Enumeration of heterotrophic and hydrocarbondegrading microbial populations. Bacterial counts from the surface sediments were performed using the miniaturized most probable number (MPN) method performed in 96-well microtiter plates with 8 replicate wells per dilution (Wrenn \& Venosa 1996). Total heterotrophs were counted in tryptone soy broth (TSB), aliphatic degraders were counted in a mineral medium called BMTM (Hareland et al. 1975), containing $1 \mathrm{~g}$ $n$-hexadecane $\mathrm{l}^{-1}$, and aromatic hydrocarbon degraders were counted in BMTM containing a mixture of phenanthrene $\left(0.5 \mathrm{~g} \mathrm{l}^{-1}\right)$, fluorene, anthracene and dibenzothiophene (each at a final concentration of $0.05 \mathrm{~g} \mathrm{l}^{-1}$ ). All the media were supplemented with $3 \%$ $\mathrm{NaCl}$. Hydrocarbon stocks were previously filtered through Teflon filters (Fluoropore $0.22 \mu \mathrm{m}$ PTFE, Millipore).

BMTM mineral medium was composed of $18.6 \mathrm{mM}$ $\mathrm{K}_{2} \mathrm{HPO}_{4} \cdot 3 \mathrm{H}_{2} \mathrm{O} ; 7.2 \mathrm{mM} \mathrm{NaH} \mathrm{PO}_{4} \cdot \mathrm{H}_{2} \mathrm{O} ; 37 \mathrm{mM} \mathrm{NH}_{4} \mathrm{Cl}_{i}$ $0.8 \mathrm{mM} \mathrm{MgSO}{ }_{4} \cdot 7 \mathrm{H}_{2} \mathrm{O} ; 43 \mu \mathrm{M} \mathrm{FeSO}{ }_{4} \cdot 7 \mathrm{H}_{2} \mathrm{O} ; 17.8 \mu \mathrm{M}$ $\mathrm{MnSO}_{4} \cdot \mathrm{H}_{2} \mathrm{O} ; 10.5 \mu \mathrm{M} \mathrm{ZnSO}{ }_{4} \cdot 7 \mathrm{H}_{2} \mathrm{O}_{4} 4.2 \mu \mathrm{M} \mathrm{CoCl}_{2}$. $6 \mathrm{H}_{2} \mathrm{O}$ and $0.5 \mathrm{mM}$ nitrilotriacetic acid disodium salt.

Isolation and identification of hydrocarbon-degrading bacteria. All isolated bacteria were screened for hydrocarbon degradation capabilities by growth in different selective media. Two media were used: one for the detection of alkane degradation and another to detect aromatic degradation activity. Both were tested on each culture using solid medium (Petri plates) and liquid medium (96-well microtitre sterile plates). Solid medium was used for the detection of alkane degraders on parafilm-sealed Petri plates containing mineral medium agar (BMTM $3 \% \mathrm{NaCl}$ solidified with purified agar) with sterile cotton soaked in hexadecane on their lids as the sole source of $\mathrm{C}$ and energy as previously described. For the isolation of aromatic degraders, naphthalene pebbles, instead of cotton, were used. Screening was carried out in duplicate for each. A negative control (bacteria growing only on purified agar) and a positive control (in marine broth) were also included in the analysis.

The second test used to detect hydrocarbon-degrading strains was carried out in liquid mineral medium $(\mathrm{BMTM}+3 \% \mathrm{NaCl})$ containing either $n$-hexadecane or a PAH mixture at the same concentrations described above for MPN enumeration. The strains were cultured overnight at room temperature in TSB. Cells were harvested by centrifugation $(4000 \times g$ for $15 \mathrm{~min})$, washed twice, and finally suspended in mineral medium (BMTM $+3 \% \mathrm{NaCl})$ to reach an optical density (OD) of around 0.5, as determined using a multiscan spectrophotometer (Labsystems) at $620 \mathrm{~nm}$. A total of $20 \mu \mathrm{l}$ of suspended cells was used for the inoculation of 2 wells per plate. Plates with BMTM without hydrocarbons were inoculated with each strain and were used as negative controls.

DNA extraction and PCR amplification of the 16S rRNA gene. Colonies were picked up from the pure cultures, suspended in $100 \mu \mathrm{l}$ of sterile milliQ water (Sigma-Aldrich Co.), boiled for $10 \mathrm{~min}$, and centrifuged for $5 \mathrm{~min}$ at $12000 \times \mathrm{g}$. Then, $2 \mu \mathrm{l}$ of supernatant was used as template DNA for PCR analysis. The complete 16S rRNA gene was amplified using the primers F27 and R1492 as previously described (Edwards et al. 1989, Lane 1991). All PCR amplifications were performed with a Perkin-Elmer GeneAmp 2700 Thermo- 
cycler (Applied Biosystems). The PCR reaction $(25 \mu \mathrm{l})$ included $10 \mathrm{mM}$ Tris, $50 \mathrm{mM} \mathrm{KCl}(\mathrm{pH} 8.3), 2.5 \mathrm{mM}$ $\mathrm{MgCl}_{2}, 400 \mu \mathrm{M}$ of each deoxynucleotide, $1.25 \mathrm{U}$ of Taq DNA polymerase (Amplitaq; PE Applied Biosystems), $0.4 \mu \mathrm{M}$ of each primer and $100 \mathrm{ng}$ of template DNA. The reaction mixtures were subjected to a hot start $\left(5 \mathrm{~min}\right.$ at $95^{\circ} \mathrm{C}$ ) and after that to the following thermal cycling parameters: (1) $5 \mathrm{~min}$ at $95^{\circ} \mathrm{C}_{i}$ (2) 40 cycles, with 1 cycle consisting of $30 \mathrm{~s}$ at $96^{\circ} \mathrm{C}$ for denaturation, $30 \mathrm{~s}$ at $55^{\circ} \mathrm{C}$ for annealing and $1.5 \mathrm{~min}$ at $72^{\circ} \mathrm{C}$ for elongation; and (3) a final extension step of $10 \mathrm{~min}$ at $72^{\circ} \mathrm{C}$. PCR products were visualized in a $1 \%(\mathrm{w} / \mathrm{v})$ agarose gel in $1 \times$ TAE buffer stained with ethidium bromide $\left(0.6 \mathrm{mg} \mathrm{ml}^{-1}\right)$.

Sequencing and phylogenetic analysis. In order to eliminate the excess of primers and dNTPs for sequencing reactions, the PCR products were digested at $37^{\circ} \mathrm{C}$ for $1 \mathrm{~h}$ using shrimp alkaline phosphatase (SAP)

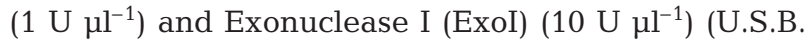
Corporation). The enzymes were afterwards inactivated by heating the samples at $80^{\circ} \mathrm{C}$ for $15 \mathrm{~min}$.

Sequencing was accomplished using the ABI Prism Big Dye Terminator cycle-sequencing reaction kit (Version 3.1) and an ABI Prism 3700 automated sequencer (PE Applied Biosystems) following the manufacturer's instructions. 16S rRNA genes were fully sequenced in both directions using a set of 6 universal primers F27, R1492, F341, R907 (Edwards et al. 1989, Lane 1991), PSL and PSR (Campbell et al. 1995). Sequences were inspected, corrected and assembled into a single consensus sequence for each phylotype. After that, the sequences were examined with the BLAST search alignment tool comparison software (BLASTN)(Altschul et al. 1990) to detect the closest bacterial group to each strain from the GenBank database.

Sequences from all phylotypes were aligned with reference sequences obtained from GenBank using ClustalX (Thompson et al. 1997). The alignment obtained was transferred to MacClade (Maddison \& Maddison 2003) and was modified using the software GBlocks (Castresana 2000) to eliminate poorly informative regions of the DNA alignment, which are convenient to delete prior to phylogenetic analysis.

The alignment obtained was finally edited using the MacClade program and directly transferred to Version $4.0 \mathrm{~b} 10$ of PAUP* software (Swofford 2000). ModelTest software Version 3.6 (Posada \& Crandall 1998) was run as a guide to determine the best-fit maximumlikelihood (ML) model for the edited alignment. We incorporated the best-fit model of nucleotide evolution, calculated by ModelTest, into the software PAUP* and PHYML (Guidon \& Gascuel 2003), which uses a single, fast and accurate algorithm to estimate large phylogenies by ML. Finally, the trees created by PHYML and
PAUP were edited using the software TreeViewX (Page 1996).

Nucleotide sequence accession numbers. The 37 bacterial 16S rDNA sequences reported in this paper are available under GenBank Accession Numbers EU195920 to EU195956.

\section{RESULTS}

\section{Chemical analysis}

The GC profiles of the aliphatic fraction of the subtidal sediment of the Cíes Islands (Station 1; Fig. 2) exhibited clear evidence of a fresh petrogenic contamination, based on occurrence of the homologous series of $\mathrm{C}_{17}$ to $\mathrm{C}_{40} n$-alkanes overlying an unresolved complex mixture of hydrocarbons. In contrast, the profiles corresponding to the other samples (e.g. Station 3; Fig. 2) exhibited the general features of rather pristine coastal environments, with the predominance of terrestrial biogenic (higher plant) $\mathrm{C}_{25}$ to $\mathrm{C}_{33} n$-alkanes with odd-even carbon number predominance and an almost absent unresolved complex mixture of hydrocarbons (Tolosa et al. 1996b). Station 5 is an exception, located inside the Vigo estuary, possibly influenced by local hydrocarbon inputs.

Confirmation of the presence of 'Prestige' oil in the Cíes Islands samples was obtained by a detailed study of the fossil biomarkers, namely steranes and triterpanes, currently used for oil spill fingerprinting (Daling et al. 2002). The diagnostic molecular parameters (Fig. 3, Table 1) indicate a clear correspondence with

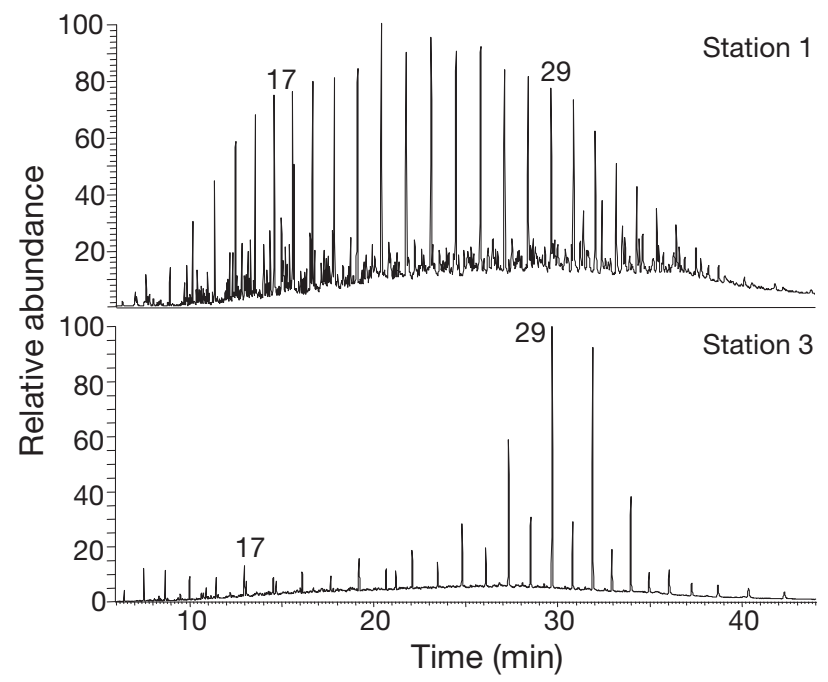

Fig. 2. Representative profiles of the sediment aliphatic fractions $(\mathrm{m} / \mathrm{z}$ 85) at Stations 1 and 3. Peak numbers indicate the number of carbon atoms of $n$-alkanes. Stations correspond to those indicated in Fig. 1. Station 3 is used as a model for the rest of the stations $(2,4,5$ and 6$)$, which show similar profiles 


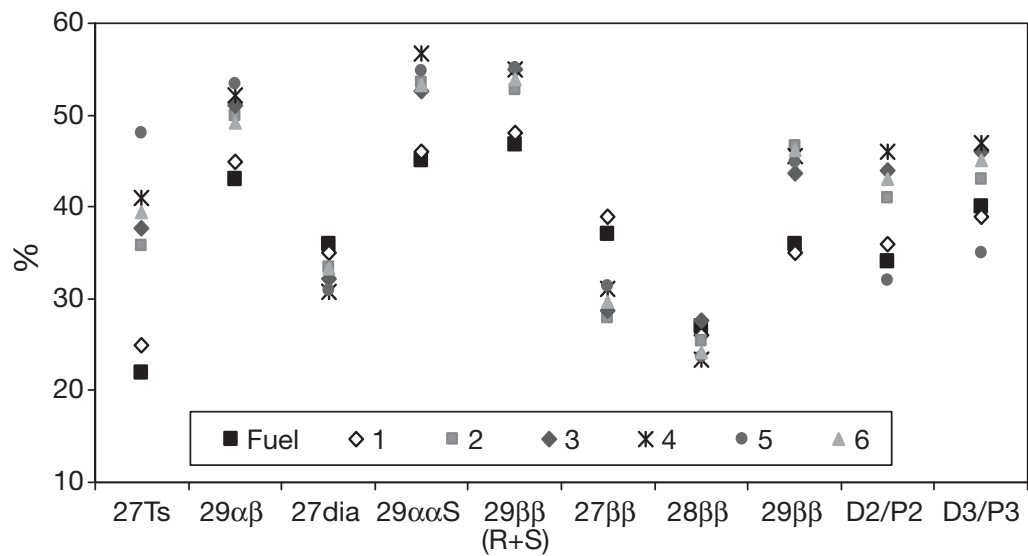

Fig. 3. Source diagnostic indices of aliphatic and aromatic hydrocarbons from the 'Prestige' oil and the sediment stations shown in Fig. 1. Indices are defined in Table 1

those of the fuel oil for Station 1, whereas Station 5 (inside the estuary) exhibits a pattern clearly different from the others.

Concurrently, the aromatic fraction of the Cíes sediments was dominated by the series of petrogenic alkyl phenanthrenes and dibenzothiophenes (Table 2), whereas the other stations exhibited distributions consistent with mixed petrogenic-pyrolytic sources, common in coastal sediments of urban/industrial areas and attributed to chronic runoff inputs. These are characterized by similar proportions of 2 to 4 aromatic ring alkylated components and the series of parent 4 - to 6 -ring PAHs, encompassing the benzo[ $b]+[k]$ fluoranthenes and benzo[a]+[b]pyrenes (Tolosa et al. 1996a).

The PAH concentrations reported in Table 2 (with the exception of Station 5) indicated moderate pollution in the subtidal samples from the Cíes Islands and low levels in other areas ( 77 to $213 \mathrm{mg} \mathrm{kg}^{-1}$ dry wt), on the order of those found on the continental shelf, inside the Vigo estuary (1858 $\mathrm{mg} \mathrm{kg}^{-1}$ dry wt). The ratios of $\mathrm{C}_{2}$ and $\mathrm{C}_{3}$ di- benzothiophenes and phenanthrene/ anthracenes (D2/P2 and D3/P3), proposed for differentiating sources of spilled oils in sediments (Douglas et al. 1996), also support the presence of 'Prestige' oil in the Cíes sediment samples (Fig. 3).

Enumeration of heterotrophic, alkane-degrading and polyaromaticdegrading microbial populations

At Station 1, the MPN results (Fig. 4) suggest a bacterial community composed of a moderately high MPN of heterotrophs $\left(10^{5} \mathrm{MPN} \mathrm{g}^{-1}\right.$ sediment $)$ of which almost $70 \%\left(10^{4}\right.$ to $\left.10^{5} \mathrm{MPN} \mathrm{g}^{-1}\right)$ belonged to the alkane-degrading population. The aromatic-degrading bacteria were also present, although in a much lower proportion (around $10^{3} \mathrm{MPN} \mathrm{g}^{-1}$ ).

\section{Culturable bacteria isolation}

Ten-fold dilutions of the sediments were spread onto marine agar 1/5. More than 60 different bacteria were randomly isolated from the most diluted plates in order to include the most frequent culturable bacteria present in the polluted sediments. Only 51 isolated bacterial strains were able to maintain their viability throughout the whole experiment.

\section{Bacterial identification and phylogenetic analysis}

A total of 51 16S rRNA gene sequences were first compared with each other to detect identical

Table 1. Diagnostic indices used as source and weathering indicators for the 'Prestige' oil samples in sediments

\begin{tabular}{|c|c|c|}
\hline Index & Definition & Structures \\
\hline $27 \mathrm{Ts}$ & $100 \times \mathrm{Ts} /(\mathrm{Ts}+\mathrm{Tm})$ & $\begin{array}{l}\text { Ts: } 18 \alpha(\mathrm{H})-22,29,30 \text {-trisnorneohopane } \\
\text { Tm: } 17 \alpha(\mathrm{H})-22,29,30 \text {-trisnorhopane }\end{array}$ \\
\hline $29 \alpha \beta$ & $100 \times 29 \alpha \beta /(29 \alpha \beta++30 \alpha \beta)$ & $\begin{array}{l}29 \alpha \beta: 17 \alpha(\mathrm{H}), 21 \beta(\mathrm{H}) \text {-30-norhopane } \times \\
30 \alpha \beta: \times 17 \alpha(\mathrm{H}), 21 \beta(\mathrm{H}) \text {-hopane }\end{array}$ \\
\hline 27 dia & $100 \times 27 d(R+S) /[27 d(R+S)+27 \beta \beta(R+S)]$ & $\begin{array}{l}27 \mathrm{~d}: 13 \beta(\mathrm{H}), 17 \alpha(\mathrm{H}) \text {-diacholestane }(20 \mathrm{~S} \text { and } 20 \mathrm{R}) \\
27 \beta \beta: 14 \beta(\mathrm{H}), 17 \beta(\mathrm{H}) \text {-cholestane }(20 \mathrm{R} \text { and } 20 \mathrm{~S})\end{array}$ \\
\hline $29 \alpha \alpha \mathrm{S}$ & $100 \times 29 \alpha \alpha \mathrm{S} /(29 \alpha \alpha \mathrm{S}+29 \alpha \alpha \mathrm{R})$ & 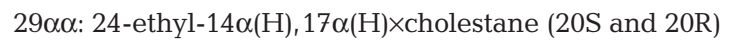 \\
\hline $29 \beta \beta(\mathrm{R}+\mathrm{S})$ & $100 \times 29 \beta \beta(\mathrm{R}+\mathrm{S}) /[29 \beta \beta(\mathrm{R}+\mathrm{S})+29 \alpha \alpha(\mathrm{R}+\mathrm{S})]$ & 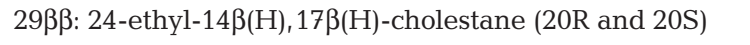 \\
\hline $27 \beta \beta$ & $100 \times[27 \beta \beta(\times \mathrm{R}+\mathrm{S})] /[27 \beta \beta(\mathrm{R}+\mathrm{S})+28 \beta \beta(\mathrm{R}+\mathrm{S})+29 \beta \beta(\mathrm{R}+\mathrm{S})]$ & $27 \beta \beta: 14 \beta(\mathrm{H}), 17 \beta(\mathrm{H})$-cholestane (20R and 20S) \\
\hline $28 \beta \beta$ & $100 \times[28 \beta \beta(\mathrm{R}+\mathrm{S})] /[27 \beta \beta(\mathrm{R}+\mathrm{S})+28 \beta \beta(\mathrm{R}+\mathrm{S})+29 \beta \beta(\mathrm{R}+\mathrm{S})]$ & 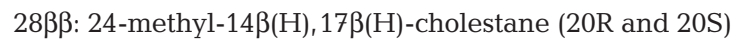 \\
\hline $29 \beta \beta$ & $100 \times[29 \beta \beta(\mathrm{R}+\mathrm{S})] /[27 \beta \beta(\mathrm{R}+\mathrm{S})+28 \beta \beta(\mathrm{R}+\mathrm{S})+29 \beta \beta(\mathrm{R}+\mathrm{S})]$ & 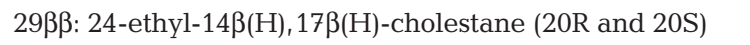 \\
\hline $\mathrm{D} 2 / \mathrm{P} 2$ & $100 \times \mathrm{D} 2 /(\mathrm{D} 2+\mathrm{P} 2)$ & Dimethyldibenzothiophenes (D2) and phenanthrenes (P2) \\
\hline D3/P3 & $100 \times \mathrm{D} 3 /(\mathrm{D} 3+\mathrm{P} 3)$ & Trimethyldibenzothiophenes (D3) and phenanthrenes (P3) \\
\hline
\end{tabular}


Table 2. Average polycyclic aromatic hydrocarbon (PAH) concentration (in mg kg dry $\mathrm{wt}^{-1}$ ) of sediments from the Cíes Islands and surrounding areas (stations as in Fig. 1). Naph: naphthalene; Phen: phenanthrene; A: anthracene; Fl: fluoranthene; Py: pyrene; D: dibenzothiophene; BaA: benz[a]anthracene; C: chrysene; B(b+k)Fl: benzo[b+k]fluoranthene; BePy: benzo[e]pyrene; BaPy: benzo[a]pyrene; Per: perylene; DBA: dibenz[ah]anthracene; BPer: benzo[ghi]perylene; IPy: indeno[1,2,3-cd ]pyrene; N1 to N3, P1 to P3, D1 to D3 and C1 to C3: the methyl to trimethyl derivatives

\begin{tabular}{|lrrrrrr}
\hline \multirow{2}{*}{ PAH } & \multicolumn{7}{c}{ Cíes Islands } & & \\
\cline { 2 - 3 } & Stn 1 & Stn 2 & Stn 3 & Stn 4 & Stn 5 & Stn 6 \\
\hline Naph & 1 & 1 & 1 & - & 20 & 2 \\
Naph 1 & 2 & 1 & 10 & 2 & 83 & 6 \\
Naph 2 & 5 & 3 & 24 & 5 & 125 & 17 \\
Naph 3 & 33 & 2 & 25 & 5 & 110 & 14 \\
Phen & 30 & 1 & 7 & 2 & 46 & 3 \\
A & 2 & - & 1 & 2 & 11 & - \\
Phen 1 & 237 & 6 & 10 & 3 & 152 & 14 \\
Phen 2 & 575 & 10 & 17 & 5 & 195 & 17 \\
Phen 3 & 460 & 12 & 12 & 6 & 232 & 15 \\
D & 31 & - & 6 & 5 & 24 & 1 \\
D1 & 146 & 3 & 8 & 2 & 42 & 6 \\
D2 & 320 & 7 & 14 & 4 & 86 & 12 \\
D3 & 310 & 8 & 11 & 5 & 115 & 12 \\
Fl & 13 & 2 & 10 & 4 & 62 & 4 \\
Py & 81 & 2 & 7 & 3 & 49 & 3 \\
BaA & 11 & 1 & 3 & 1 & 21 & 2 \\
C & 19 & 2 & 4 & 2 & 37 & 3 \\
C1 & 80 & 2 & 4 & 2 & 42 & 6 \\
C2 & 75 & 3 & 4 & 2 & 45 & 12 \\
C3 & 54 & 3 & 3 & 2 & 34 & 13 \\
B(b+k)Fl & 2 & 4 & 11 & 5 & 113 & 7 \\
BePy & 6 & 2 & 4 & 2 & 43 & 4 \\
BaPy & 4 & 3 & 3 & 1 & 41 & 5 \\
Per & 2 & 4 & 7 & 2 & 48 & 15 \\
DBA & 1 & 2 & - & 1 & 12 & 3 \\
IPy & 1 & 3 & 4 & 2 & 36 & 4 \\
BPer & 2 & 3 & 3 & 2 & 34 & 4 \\
Total & 2503 & 90 & 213 & 77 & 1858 & 204 \\
& & & & & & \\
\hline
\end{tabular}

sequences by using Clustal $\mathrm{X}$. Of these, 37 were different (Table 3) and were used to construct a whole alignment with sequences of known type species. After the first modifications in MacClade (cutting off left and right ends of the alignment), the number of characters in the alignment (approximately 1300) was reduced to only 737 after using GBlocks to make the alignment more suitable for phylogenetic analysis. Type strains from genera belonging to the phyla Proteobacteria and Firmicutes and members of the Bacteroidetes were used. The total alignment of 87 sequences ( 37 phylotypes plus type strain sequences) was used to estimate the taxonomic position of phylotypes by maximum likelihood, following the Tamura-Nei (TrN) model recommended by ModelTest. Phylogenetic analysis showed that most of our bacteria belonged to the Gammaproteobacteria (29 out of 37), followed by the Alphaproteobacteria ( 7 out of 37), Bacteroidetes (4 out of 37) and Firmicutes (4 out of 37). The highest richness

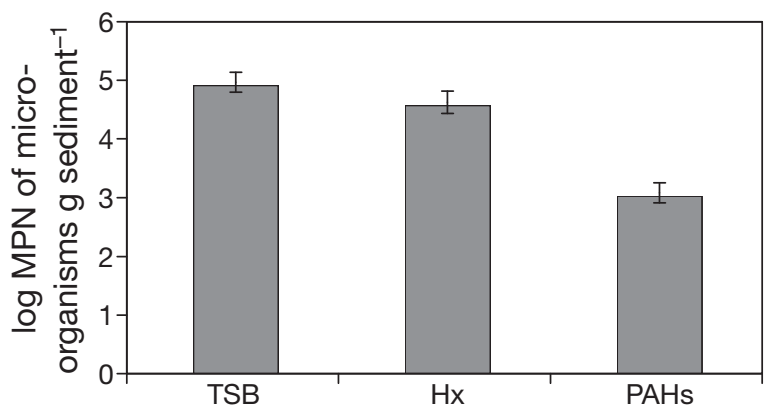

Fig. 4. Most probable number (MPN) of bacteria per gram of sediment for each trophic community (log MPN). TSB: total heterotrophic community; Hx: alkane-degrading population; PAHs: aromatic-degrading bacteria. Error bars = standard deviations

was found in the Gammaproteobacteria group with strains of the genera Marinomonas, Shewanella, Vibrio, Psychrobacter, Alcanivorax and Pseudoalteromonas. Among the Alpharoteobacteria, strains similar to the genus Roseobacter and others of difficult adscription were detected. Four strains were similar to members of the Bacteroidetes group, e.g. the genera Brumimicrobium, Dokdonia, Winogradskyella and Cytophaga, whilst the rest showed high similarity to Firmicutes, e.g. Bacillus and Staphylococcus.

\section{Screening of degrading capability and phylogenetic analysis}

Only 7 strains belonging to the same phylotype out of the 37 marine agar-culturable bacteria showed alkanedegrading activity, growing on hexadecane vapors and in liquid-medium BMTM supplemented with hexadecane as the sole source of $\mathrm{C}$ and energy. Because of our interest in alkane-degraders, a specific phylogenetic analysis was carried out by means of parsimony criterion with bootstrap values. The phylogenetic tree (Fig. 5) grouped the 7 strains belonging to the same phylotype as Alcanivorax borkumensis with a boostrap value of 100 . However, no PAH-degrading bacteria could be detected among any of the 37 isolated strains.

\section{DISCUSSION}

The oil-polluted sediment selected for isolation of bacteria in the current study presented a high degree of fresh hydrocarbon pollution characterized by fingerprint indexes of unweathered fuel from the 'Prestige' spill and a high preservation of the $n$-alkane series (Fig. 2), which may still have supported the bloom of obligate hydrocarbonoclastic bacteria at the time of sampling. 
Table 3. Results from the phylogenetic tree and the BLASTN comparison (performed on November 2006) of our 51 sequences with those stored in GenBank. The table contains the names and accession numbers of the species most similar to each of the 51 studied isolates. ' $=$ ' between 2 strains means that its sequences are identical

\begin{tabular}{|c|c|c|c|}
\hline Phylogenetic group & $\begin{array}{l}\text { Closest organism from GenBank database } \\
\text { (accession no.) in phylogenetic tree }\end{array}$ & Identities \% & Isolate \\
\hline \multicolumn{4}{|l|}{ Gammaproteobacteria (59\%) } \\
\hline \multirow[t]{3}{*}{ Alteromonadaceae $13.8 \%$} & Marine bacterium Tw-5 (AY028200) & 99 & P72 \\
\hline & Marine bacterium Neptune (AY082669) & $98-99$ & $\mathrm{P} 77=\mathrm{P} 86$ \\
\hline & Alteromonadaceae bacterium R2 (AF539784) & $98-99$ & $\mathrm{P} 76$ / P78'/ P82 / P120 \\
\hline \multirow[t]{2}{*}{ Shewanellaceae $9.8 \%$} & Shewanella baltica (AF173966) & 99 & $\mathrm{P} 80 / \mathrm{P} 96 / \mathrm{P} 97=\mathrm{P} 105$ \\
\hline & Shewanella colwelliana (AY653177) & 100 & P117 \\
\hline \multirow[t]{3}{*}{ Pseudoalteromonadaceae $7.8 \%$} & Pseudoalteromonas sp. YASM-7 (DQ173045) & 99 & P94 \\
\hline & Pseudoalteromonas sp. SM9913 (AY305857) & 99 & P102 \\
\hline & Pseudoalteromonas sp. ARCTIC-P16 (AY573035) & 99 & $\mathrm{P} 108={ }^{\mathrm{a}} \mathrm{P} 118$ \\
\hline \multirow[t]{3}{*}{ Vibrionaceae $5.8 \%$} & Vibrio sp. V798 (DQ146994) & 99 & P90 \\
\hline & Vibrio sp. Da4 (AF242272) & 99 & P121 \\
\hline & Bacterium CWISO12 (DQ334350) & 99 & P124 \\
\hline \multirow[t]{3}{*}{ Oceanospirillales $5.8 \%$} & Marinomonas aquimarina 11OM3 (AJ843079) & 97 & P111 \\
\hline & Marinomonas primoryensis (AY771708) & 97 & $\mathrm{P} 115$ \\
\hline & Oceanospirillum multiglobuliferum (AB006764) & 93 & P95 \\
\hline Moraxellaceae $2 \%$ & Psychrobacter sp. B-5161 (DQ399762) & 99 & P116 \\
\hline Alcanivoraceae $14 \%$ & $\begin{array}{l}\text { Gamma proteobacterium ST1 (AB005655) } \\
\text { (Alcanivorax borkumensis) }\end{array}$ & $99-100$ & $\begin{array}{c}\mathrm{P} 75=\mathrm{P} 78 \mathrm{Hx}=\mathrm{P} 79 \mathrm{n}= \\
\mathrm{P} 83=\mathrm{P} 84 \mathrm{Hx}=\mathrm{P} 99 \mathrm{n}=\mathrm{P} 101 \mathrm{n}\end{array}$ \\
\hline \multicolumn{4}{|l|}{ Bacteroidetes (10\%) } \\
\hline & Dokdonia donghaensis DSW-21 (DQ003277) & 99 & P79 \\
\hline & Winogradskyella sp. BC1 (DQ356490) & 98 & P101 \\
\hline & Marine bacterium BBFL7 (AY028207) & 99 & $\mathrm{P} 84=\mathrm{P} 100$ \\
\hline & Brumimicrobium mesophilum (DQ660382) & 97 & P99 \\
\hline \multicolumn{4}{|l|}{ Alphaproteobacteria (21\%) } \\
\hline \multirow[t]{7}{*}{ Rhodobacteraceae $21 \%$} & Roseobacter sp. 14III/A01/004 (AY576690) & 100 & P73 \\
\hline & Rhodobacteraceae bacterium 197 (AJ810843) & 98 & $\mathrm{P} 87=\mathrm{P} 92$ \\
\hline & Octadecabacter orientus KOPR...(DQ167247) & 97 & P104 \\
\hline & Agrobacterium meteori (D88527) & 99 & P128 \\
\hline & Roseobacter gallaeciensis (AJ867255) & 97 & P74 \\
\hline & Roseobacter sp. 3008 (AM110967) & 96 & $\mathrm{P} 78=\mathrm{P} 81=\mathrm{P} 85=\mathrm{P} 88$ \\
\hline & Roseobacter sp. JL-126 (AY745859) & 96 & P123 \\
\hline \multicolumn{4}{|l|}{ Firmicutes (10\%) } \\
\hline & Bacillus sp. NT N86 (AB167010) & 99 & P122 \\
\hline & Staphylococcus pasteuri CV5 (AJ717376) & 100 & P106 \\
\hline & Staphylococcus pasteuri ZA-b3 (AF532917) & $99-100$ & $\mathrm{P} 107=\mathrm{P} 126$ \\
\hline & Bacillus sp. 19493 (AJ315061) & 95 & P109 \\
\hline
\end{tabular}

Petroleum pollution may stimulate the growth of hydrocarbon-degrading microorganisms that usually exist in low abundance in sediments, shifting the community structure of the affected sites. Previous studies have reported dominance of Gammaproteobacteria in bacterial communities from oil-affected marine habitats. However, the samples in these experiments had been recently affected (Roling et al. 2002), or had been retrieved from places where natural attenuation proceeded slowly, such as the Sea of Japan (Kasai et al. 2001).
However, communities from samples enriched with nutrients, or from places where high nutrient levels (0.8 $\mathrm{mg} \mathrm{l}^{-1}$ of total nitrogen) naturally occur (Macnaughton et al. 1999), presented Gammaproteobacteria-dominated communities, which were rapidly substituted by Alphaproteobacteria due to higher rates of biodegradation. Disappearance of Gammaproteobacteria was linked to a loss of Alcanivorax dominance in the community, and this change in the community was faster when amended with nutrients (Roling et al. 2002, 2004). In most cases in which Alcanivorax spp. 


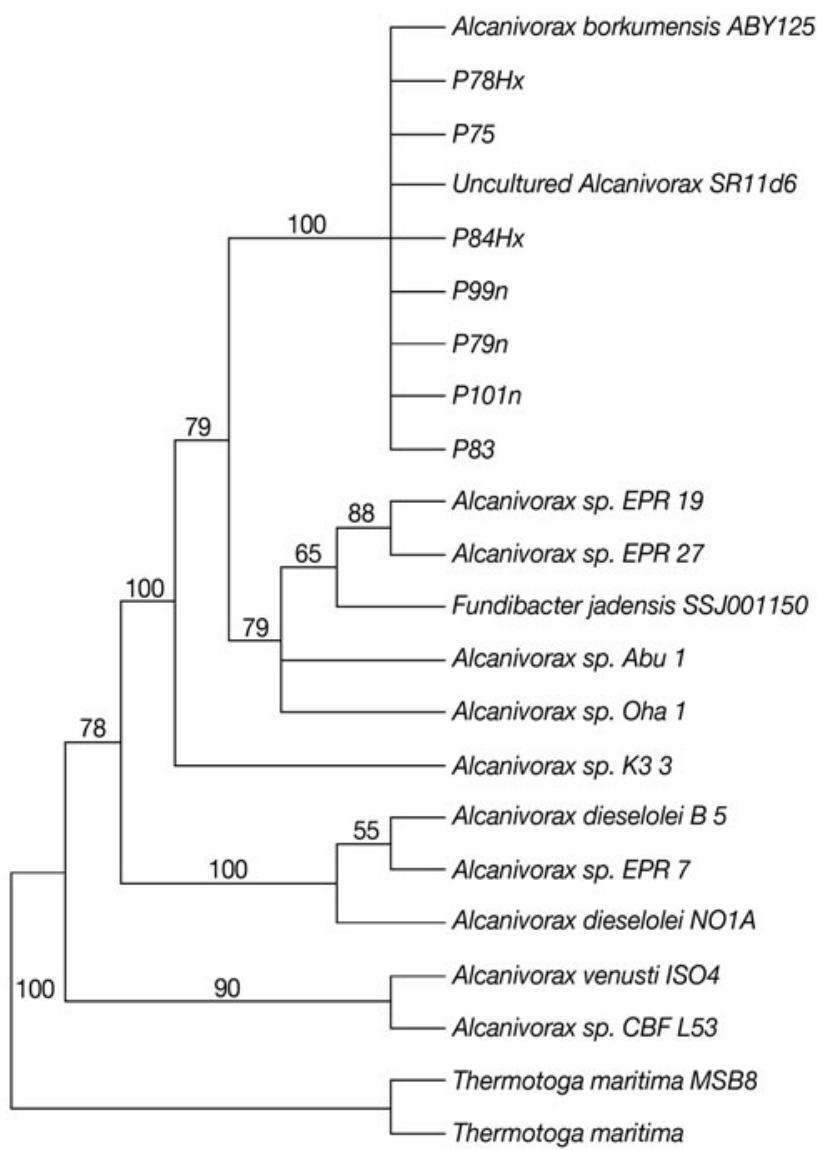

Fig. 5. Maximum-parsimony phylogeny (based on complete 16S rDNA sequences) for the positive alkane-degrading phylotypes. The tree construction was performed using PAUP* ${ }^{*}$ software following the Tamura-Nei+I+G model of nucleotide evolution and likelihood settings (rates = gamma; shape $=0.6768$; pinvar $=0.4386$ ) recommended by ModelTest. Bootstrap values on nodes (100 replicates) are only shown when $>50 \%$. Thermotoga spp. were used to root the tree

have been found to be dominant in oil-impacted environments, samples were analyzed within days of the oil pollution or bioremediation event. In samples retrieved $>8$ wk after the start of the experiments (Kasai et al. 2001, Maruyama et al. 2003), no such dominance was detected. In these cases, it is possible that the Alcanivorax spp. bloom had already occurred (Macnaughton et al. 1999), or that the nutrient levels and alkane percentage of the spilled oil, critical for the growth of this genus, were too low ('Nakhodka', Sea of Japan) (Kasai et al. 2001, 2002). All this is consistent with the observation that, after an initial rapid increase in population size, Alcanivorax spp. decline to much lower numbers within weeks (Syutsubo et al. 2001, Roling et al. 2002, 2004).

Polluted samples considered in the present study were retrieved 3 mo after the last fuel input from the
'Prestige'. Since low amounts of alkanes were present in the 'Prestige' oil and high biodegradation rates were expected in the ría (Medina-Bellver et al. 2005), such a length of time would have already produced the Alcanivorax bloom long before sampling. Indeed, degradation of the fuel present at the rest of the stations was quite advanced, compared to that at Station 1. Sea currents probably transported buried oil from other places to Station 1, supplying its sediments with unweathered oil (Fig. 3) rich in alkanes (Fig. 2), which enabled the growth and, thus, the isolation of Alcanivorax at that station.

Most of the isolated bacteria found in Cíes sediments were identified as members of the Gammaproteobacteria (59\%) (Table 3). Members of Alteromonas, Shewanella, Pseudoalteromonas, Vibrio, Marinomonas, Psychrobacter and Alcanivorax were identified. Although only the 7 strains (Table 3 ) from the phylotype close to Alcanivorax borkumensis (Fig. 5) were able to degrade alkanes, hydrocarbon-degrading strains have been previously described in all the isolated genera. For example, phenanthrene- and chrysene-degrading activities have been observed among members of the genera Vibrio, Pseudoalteromonas and Marinomonas (Melcher et al. 2002). Shewanella spp. able to grow on crude oil, tetradecane and naphthalene (Gentile et al. 2003) have also been detected. Concerning the Alphaproteobacteria group, among the 4 isolated strains, P73 corresponded to Roseobacter sp. $(100 \%)$ and Strain P128 belonged to the genus Agrobacterium (99\%) (Table 3). Some species of these 2 genera have been described as PAH degraders (Widdel \& Rabus 2001). Finally, 4 non-hydrocarbon-degrading strains, belonging to the Bacteroidetes and Firmicutes groups, were isolated. Only some species of the genus Staphylococcus have been previously described as naphthalene degraders (Zhuang et al. 2003).

The PAHs present in the 'Prestige' fuel were mainly of high molecular weight (3 or more aromatic rings), leading to a low PAH bioavailability. The PAH concentrations measured at the time of sampling were very low (around $2.5 \mathrm{\mu g} \mathrm{g}^{-1}$ for Station 1; Table1). The small population $\left(10^{3} \mathrm{MPN} \mathrm{g}^{-1}\right)$ of PAH-degrading bacteria detected could be explained by this low concentration and bioavailability. The fact that no aromatic-degrading activity was detected among the isolated bacteria did not necessarily mean that they do not play a role in the biodegradation processes. Microbial communities are mainly naturally selected by their metabolic cooperation. Although several members of the microbial community could be secondary hydrocarbon degraders, their success could be related to co-metabolism, supply of growth factors for solubilization of substrates and/or elimination of toxic metabolites (Kanaly et al. 2002). In a previous study on a hydrocarbon-degrading 
co-culture, the importance of a non-degrading strain that eliminates an intermediate metabolite produced by the hydrocarbon-degrading strain was demonstrated (Casellas et al. 1998). Obviously, taking into account that the specific richness of the present study has been detected on diluted marine agar-culturable bacteria, other non-culturable species could fulfill critical roles in the global microbial community, as recently described in a hydrocarbon-degrading consortium (Vinas et al. 2005b). All but one of the isolated genera exhibited an absence of hydrocarbondegrading capabilities. The low amount of degrading bacteria isolated was expected from the beginning, since no selective medium was used to isolate degrading bacteria.

The Russian tanker 'Nakhodka' released heavy oil, with a composition very similar to that of the 'Prestige' spill, which covered $>500 \mathrm{~km}$ of the Japanese coastline. The levels of $\mathrm{N}$ and $\mathrm{P}\left(0.1\right.$ and $0.01 \mathrm{mg} \mathrm{l}^{-1}$, respectively) in the Sea of Japan are relatively small, which may have hindered Alcanivorax from dominating the microbial community. When $\mathrm{N}$ and $\mathrm{P}$ were added in adequate quantities to cultures of seawater with crude oil as the only source of C, Alcanivorax became dominant and the rate of biodegradation was strongly promoted (Kasai et al. 2001, 2002, Roling et al. 2002). However, this effect could only be shown in batch cultures and was not observed in situ, due to low levels of naturally occurring nutrients.

Since the oil from the 'Nakhodka' had a similar composition to that from the 'Prestige' (heavy fuel) and Alcanivorax phylotypes were isolated in high proportion without nutrient amendments in the Vigo estuary, it can be hypothesized that the environmental conditions along the Atlantic coast could be more suitable to biodegradation than those in the Sea of Japan (total $\mathrm{N} \approx 0.1 \mathrm{mg} \mathrm{l}^{-1}$ ). In fact, ongoing natural bioremediation has already been observed to occur along Galician coasts (Medina-Bellver et al. 2005).

In the Ría de Vigo, in addition to the boundary conditions that usually determine the patterns of circulation in estuarine systems, an additional factor must be taken into account. The coastal upwelling, as a consequence of the wind regime over the adjacent shelf, induces the inflow of subsurface oceanic eastern North Atlantic Central Water (ENAW) into the estuaries of Galicia. This inflow has a major influence on their hydrography. During the upwelling and as a consequence of the circulation pattern, part of the biomass that is produced inside the estuary is transported offshore by the outgoing surface current. Part of this exported organic matter is remineralized either in the water column or on the bottom of the continental shelf, and therefore the incoming bottom current supplies the Galician estuaries not only with new nutrients but also with remineralized nutrients through a feedback mechanism (Alvarez-Salgado et al. 1993). This fertilizing process causes the Vigo estuary to be a highly productive ecosystem that processes a considerable amount of dissolved $\mathrm{N}$ and $\mathrm{P}$ (mean values around 0.6 and $0.06 \mathrm{mg} \mathrm{l}^{-1}$, respectively, reaching even higher concentrations at certain times of the year; Nigeria et al. 1997), which is 6 times higher than the total amount of N and P in the Sea of Japan. Furthermore, the sediments from Station 1 where sandy gravel with a low organic matter content and thus well oxygenated (Vilas et al. 2005), enhancing the degradation capacity of the aerobic Alcanivorax (Yakimov et al. 1998).

Both the high proportion of the alkane-degrading population $(\approx 70 \%$ of the total MPN bacteria) and the presence of Alcanivorax as the only $n$-alkane degrader could reflect an initial shift in the microbial community towards a new assemblage more adapted to hydrocarbon contamination, as previously observed in microcosm experiments (Roling et al. 2002). Taking into account that $14 \%$ of the isolates were classified as Alcanivorax borkumensis, despite the fact that this is a 'professional hydrocarbonoclastic bacteria', it could be concluded that a high proportion of this genus should be present in the sediments sampled, being able to compete and grow on the marine agar we used for isolation. The same method for isolation was used to count growing cells of Alcanivorax in oil-contaminated seawater supplemented with $\mathrm{N}$ and $\mathrm{P}$ fertilizers (Kasai et al. 2002), and good correlation between colonies and direct cell counts by fluorescent in situ hybridization (FISH) (Syutsubo et al. 2001) was obtained. Different genotypes of Alcanivorax might be adapted to environments with different concentrations of nutrients (Head et al. 2006), suggesting that the Alcanivorax strain isolated in this study could be more adapted to competence under high nutrient levels. Although further studies are needed to confirm that hypothesis, such an ability would be a good feature for bioremediation purposes.

Our results are in agreement with the enrichment cultures made after the 'Nakhodka' oil spill in the Sea of Japan (Kasai et al. 2002, Maruyama et al. 2003), but, in our case, no enrichment was necessary. The presence of fresh fuel (preservation of the $n$-alkane series; Figs. 2 \& 3) and the high nutrient availability normally present in the Ría de Vigo support the growth of Alcanivorax, allowing its presence in quantities sufficient to be isolated without enrichment, even when competing with other heterotrophic bacteria.

Many previous studies have stated that Alcanivorax could play a critical role in the natural cleaning of oil-polluted marine systems, since the natural attenuation processes were accelerated when this species began to become dominant (Kasai et al. 2002). Unfor- 
tunately, the present study did not yield data showing whether any acceleration is actually happening. However, the presence of Alcanivorax could be used as a bioindicator in correlation with high rates of biodegradation. Indeed, the capacity of indigenous bacteria from the shore samples of the Galician coastline for biodegradation of the 'Prestige' oil has also been recently confirmed by Medina-Bellver et al. (2005).

The isolation of Alcanivorax strains directly from polluted sediment containing hydrocarbons is the first ecological evidence of the high natural abundance of this group of bacteria. Since the addition of fertilizers to the seawater would have no effect on the concentration of $\mathrm{N}$ and $\mathrm{P}$ in this area, the use of bioremediation, understood as the artificial addition of nutrients, is not advisable. Hydrocarbon-degrading populations seem to grow quite well by themselves under the environmental conditions of the Ría de Vigo. However, there may be exposed areas where the conditions are not as favorable and where bioremediation amendments could be effective.

Acknowledgements. This research was supported by the project VEM 2003-20068-C05-01 from the Spanish Ministerio de Educación y Ciencia. The authors acknowledge the Centro de Investigaciones Submarinas (CIS) for providing the sediment samples. J.A.G. and M.M.C. thank the Ministerio de Educación y Ciencia for their predoctoral fellowships.

\section{LITERATURE CITED}

Abraham WR, Meyer H, Yakimov M (1998) Novel glycine containing glucolipids from the alkane using bacterium Alcanivorax borkumensis. Bba-Lipid Lipid Met 1393: $57-62$

Altschul SF, Gish W, Miller W, Myers EW, Lipman DJ (1990) Basic local alignment search tool. J Mol Biol 215:403-410

Alvarez-Salgado XA, Rosón G, Pérez FF, Pazos Y (1993) Hydrographic variability off the Rías Baixas (NW Spain) during the upwelling season. J Geophys Res 98(C8): $14447-14455$

Alzaga R, Montuori P, Ortiz L, Bayona JM, Albaiges J (2004) Fast solid-phase extraction-gas chromatography-mass spectrometry procedure for oil fingerprinting - Application to the Prestige oil spill. J Chromatogr A 1025:133-138

- Campbell PW, Phillips JA, Heidecker GJ, Krishnamani MRS, Zahorchak R, Stull TL (1995) Detection of Pseudomonas (Burkholderia) cepacia using PCR. Pediatr Pulmonol 20: 44-49

> Casellas M, Grifoll M, Sabate J, Solanas AM (1998) Isolation and characterization of a 9-fluorenone-degrading bacterial strain and its role in synergistic degradation of fluorene by a consortium. Can J Microbiol 44:734-742

- Castresana J (2000) Selection of conserved blocks from multiple alignments for their use in phylogenetic analysis. Mol Biol Evol 17:540-552

> Cuny P, Miralles G, Cornet-barthaux V, Acquaviva M, Stora G, Grossi V, Gillbert F (2007) Influence of bioturbation by the polychaete Nereis diversicolor on the structure of bacterial communities in oil contaminated coastal sediments.
Mar Pollut Bull 54:452-459

Daling PS, Faksness LG, Hansen AB, Stout SA (2002) Improved and standardized methodology for oil spill fingerprinting. Environ Forensics 3:263-278

> Diez S, Sabate J, Vinas M, Bayona JM, Solanas AM, Albaiges J (2005) The Prestige oil spill. I. Biodegradation of a heavy fuel oil under simulated conditions. Environ Toxicol Chem 24:2203-2217

$>$ Douglas GS, Bence AE, Prince RC, McMillen SJ, Butler EL (1996) Environmental stability of selected petroleum hydrocarbon source and weathering ratios. Environ Sci Technol 30:2332-2339

Edwards U, Rogell T, Blöker H, Emde M, Böttger EC (1989) Isolation and direct complete nucleotide determination of entire genes-characterization of a gene coding for 16Sribosomal RNA. Nucleic Acids Res 17:7843-7853

Fernandez-Martinez J, Pujalte MJ, Garcia-Martinez J, Mata M, Garay E, Rodriguez-Valera F (2003) Description of Alcanivorax venustensis sp. nov. and reclassification of Fundibacter jadensis DSM 12178(T) (Bruns and BertheCorti 1999) as Alcanivorax jadensis comb. nov., members of the emended genus Alcanivorax. Int J Syst Evol Microbiol 53:331-338

Gentile G, Bonasera V, Amico C, Giuliano L, Yakimov MM (2003) Shewanella sp. GA-22, a psychrophilic hydrocarbonoclastic antarctic bacterium producing polyunsaturated fatty acids. J Appl Microbiol 95:1124-1133

Golyshin PN, Dos Santos V, Kaiser O, Ferrer M and others (2003) Genome sequence completed of Alcanivorax borkumensis, a hydrocarbon-degrading bacterium that plays a global role in oil removal from marine systems. J Biotechnol 106:215-220

Guidon S, Gascuel O (2003) PHYML-A single, fast and accurate algorithm to estimate large phylogenies by maximum likelihood. Syst Biol 52:696-704

> Hara A, Syutsubo K, Harayama S (2003) Alcanivorax which prevails in oil-contaminated seawater exhibits broad substrate specificity for alkane degradation. Environ Microbiol 5:746-753

Harayama S, Kishira H, Kasai Y, Shutsubo K (1999) Petroleum biodegradation in marine environments. J Mol Microbiol Biotechnol 1:63-70

Harayama S, Kasai Y, Hara A (2004) Microbial communities in oil-contaminated seawater. Curr Opin Biotechnol 15: 205-214

- Hareland WA, Crawford RL, Chapman PJ, Dagley S (1975) Metabolic function and properties of 4-hydroxyphenylacetic acid 1-hydroxylase from Pseudomonas acidovorans. J Bacteriol 121:272-285

> Head IM, Jones DM, Roling WFM (2006) Marine microorganisms make a meal of oil. Nat Rev Microbiol 4:173-182

> Jiménez N, Viñas M, Sabaté J, Díez S, Bayona JM, Solanas AM, Albaiges J (2006) The Prestige oil spill. II. Enhanced biodegradation of a heavy fuel oil under field conditions by the use of an oleophilic fertilizer. Environ Sci Technol 40:2578-2585

Jiménez N, Viñas M, Bayona JM, Albaiges J, Solanas AM (in press) The Prestige oil spill: Bacterial community dynamics during a field biostimulation assay. Appl Microbiol Biotechnol

> Kanaly RA, Harayama S, Watanabe K (2002) Rhodanobacter sp. strain BPC1 in a benzo[a]pyrene-mineralizing bacterial consortium. Appl Environ Microbiol 68:5826-5833

> Kasai Y, Kishira H, Syutsubo K, Harayama S (2001) Molecular detection of marine bacterial populations on beaches contaminated by the Nakhodka tanker oil-spill accident. Environ Microbiol 3:246-255 
Kasai Y, Kishira H, Sasaki T, Syutsubo K, Watanabe $\mathrm{K}$, Harayama S (2002) Predominant growth of Alcanivorax strains in oil-contaminated and nutrient-supplemented sea water. Environ Microbiol 4:141-147

Lane DJ (1991) 16S/23S sequencing. In: Stackenbrandt E, Goodfellow M (eds) Nucleic acid techniques in bacterial systematics. John Wiley and Sons, Chichester, p 115-175

Liu C, Shao ZZ (2005) Alcanivorax dieselolei sp. nov., a novel alkane-degrading bacterium isolated from sea water and deep-sea sediment. Int $\mathrm{J}$ Syst Evol Microbiol 55: 1181-1186

Macnaughton SJ, Stephen JR, Venosa AD, Davis GA, Chang YJ, White DC (1999) Microbial population changes during bioremediation of an experimental oil spill. Appl Environ Microbiol 65:3566-3574

Maddison DR, Maddison WP (2003) MacClade 4: analysis of phylogeny and character evolution, Version 4.06. Sinauer Associates, Sunderland, MA

Maruyama A, Ishiwata H, Kitamura K, Sunamura M, Fujita T, Matsuo M, Higashihara T (2003) Dynamics of microbial populations and strong selection for Cycloclasticus pugetii following the Nakhodka oil spill. Microb Ecol 46:442-453

> Medina-Bellver JI, Marin P, Delgado A, Rodriguez-Sanchez A, Reyes E, Ramos JL, Marques S (2005) Evidence for in situ crude oil biodegradation after the Prestige oil spill. Environ Microbiol 7:773-779

Melcher RJ, Apitz SE, Hemmingsen BB (2002) Impact of irradiation and polycyclic aromatic hydrocarbon spiking on microbial populations in marine sediment for future aging and biodegradability studies. Appl Environ Microbiol 68:2858-2868

> Nogueira E, Pérez FF, Ríos AF (1997) Seasonal patterns and long-term trends in an estuarine upwelling ecosystem (Ría de Vigo, NW Spain). Estuar Coast Shelf Sci 44:285-300

Page RD (1996) Tree View: an application to display phylogenetic trees on personal computers. Comput Appl Biosci 12:357-358

Posada D, Crandall KA (1998) Modeltest: testing the model of DNA substitution. Bioinformatics 14:817-818

Roling WFM, Milner MG, Jones DM, Lee K, Daniel F, Swannell RJP, Head IM (2002) Robust hydrocarbon degradation and dynamics of bacterial communities during nutrientenhanced oil spill bioremediation. Appl Environ Microbiol 68:5537-5548

Roling WFM, Milner MG, Jones DM, Fratepietro F, Swannell RPJ, Daniel F, Head IM (2004) Bacterial community dynamics and hydrocarbon degradation during a field-scale evaluation of bioremediation on a mudflat beach contaminated with buried oil. Appl Environ Microbiol 70: 2603-2613

Swannell RPJ, Lee K, McDonagh M (1996) Field evaluations of marine oil spill bioremediation. Microbiol Rev 60:342-365

Editorial responsibility: Matthias Seaman,

Oldendorf/Luhe, Germany
Swofford DL (2000) PAUP*. Phylogenetic analysis using parsimony ( ${ }^{*}$ and other methods), Version 4. Sinauer Associates, Sunderland, MA

> Syutsubo K, Kishira H, Harayama S (2001) Development of specific oligonucleotide probes for the identification and in situ detection of hydrocarbon-degrading Alcanivorax strains. Environ Microbiol 3:371-379

Thompson JD, Gibson TJ, Plewniak F, Jeanmougin F, Higgins DG (1997) The CLUSTAL_X windows interface: flexible strategies for multiple sequence alignment aided by quality analysis tools. Nucleic Acids Res 25:4876-4882

Tolosa I, Bayona JM, Albaiges J (1996a) Aliphatic and polycyclic aromatic hydrocarbons and sulfur/oxygen derivatives in northwestern Mediterranean sediments: spatial and temporal variability, fluxes, and budgets. Environ Sci Technol 30:2495-2503

Tolosa I, Bayona JM, Albaiges J (1996b) Aliphatic and polycyclic aromatic hydrocarbons and sulfur/oxygen derivatives in northwestern Mediterranean sediments: spatial and temporal variability, fluxes, and budgets. Environ Sci Technol 30:2495-2503

> Vilas F, Bernabéu AM, Méndez G (2005) Sediment distribution pattern in the Rías Baixas (NW Spain): main facies and hydrodynamic dependence. J Mar Syst 54:261-276

> Vinas M, Sabate J, Espuny MJ, Solanas AM (2005a) Bacterial community dynamics and polycyclic aromatic hydrocarbon degradation during bioremediation of heavily creosote-contaminated soil. Appl Environ Microbiol 71: 7008-7018

- Vinas M, Sabate J, Guasp C, Lalucat J, Solanas AM (2005b) Culture-dependent and -independent approaches establish the complexity of a PAH-degrading microbial consortium. Can J Microbiol 51:897-909

Widdel F, Rabus R (2001) Anaerobic biodegradation of saturated and aromatic hydrocarbons. Curr Opin Biotechnol 12:259-276

- Wrenn BA, Venosa AD (1996) Selective enumeration of aromatic and aliphatic hydrocarbon degrading bacteria by a most-probable-number procedure. Can J Microbiol 42: $252-258$

> Yakimov MM, Golyshin PN, Lang S, Moore ERB, Abraham WR, Lunsdorf H, Timmis KN (1998) Alcanivorax borkumensis gen. nov., sp. nov., a new, hydrocarbon-degrading and surfactant-producing marine bacterium. Int J Syst Bacteriol 48:339-348

Yakimov MM, Timmis KN, Golyshin PN (2007) Obligate oildegrading marine bacteria. Curr Opin Biotechnol 18: $257-266$

Zhuang WQ, Tay JH, Maszenan AM, Tay ST (2003) Isolation of naphthalene-degrading bacteria from tropical marine sediments. Water Sci Technol 47(1):303-308

Submitted: January 14, 2007; Accepted: January 28, 2008

Proofs received from author(s): June 17, 2008 